of the lungs probably 90 will show good results with no other treatment than improved hygiene and feeding. If any new treatment were applied to such cases one could easily be persuaded that it was successful. Naturally one would always wish to carry on a treatment in an early stage, but judgment of the effect of $\mathrm{such}$ treatment would be futile. For this reason I have only tested the treatment on severe and even desperate cases, thinking it better to meet with some failures if only one could get good results in a few cases where other remedies might have probably been useless. I append a few of such results, to be followed by a further series shortly. The test points are the steadying and reduction of hectic temperature, the quieting of the circulation, the diminution of the amount of sputum, the disappearance therefrom of pus and of the tubercle bacillus and other germs, and the abolition of such physical signs as indicate active tuberculous mischief.

I will tell you, here, the method which I have pursued in testing for such results. In hospital and elsewhere I have treated thus some 50 persons. Some of them were at the Brompton Hospital with surroundings, feeding, and discipline specially designed for their complaint. Others were treated at St. Mary's Hospital with the ordinary course of dietary, \&c., pursued in a general hospital. And not all of these had the intensive treatment which of late I have adopted." Dr. R. G. Reid of Lambeth has in consultation with me treated some 20 patients who might be considered equivalent to those at the Brompton Hospital, but with their own home surroundings. Dr. A. Findlater of Edgware, who is in charge of the Hendon Workhouse Infirmary, has similarly treated seven cases with practically home surrourdings, but also in a country atmosphere, or as near that as one could obtain within easy reach of supervision from London. I must not here give you details of these cases but merely the summary of the results. Almost every case has shown some improvement and in some this has been very marked. Most usually in my own cases the physical signs have diminished in amount as the earliest indication of improvement; appetite and general condition have been better after injection, and in nearly every case the patient bas gained weight. The sputum became more frothy and less purulent and in a few cases tubercle bacilli and other germs have already disappeared. I show you here one such patient. He came under my charge at St. Mary's Hospital in the autumn suffering from a very marked outbreak of the multiple pleuritic form of tuberculosis. His temperature, as you see, showed a rapid decrease, his physical signs diminished, tubercle bacilli disappeared from his sputum, and now he seems to be perfectly well. If you will examine his chest you will find nothing but some thickening of pleura in patches on the left side Dr. Reid's cases have shown similar results in spite of the somewhat hard circumstauces under which the patients were placed. Dr. Findlater, who is here to night, will tell you himself of his results, one in particular being extraordinary.

The patients should be carefully watched during the treatment, for you have heard how 1 myself suffered from the effects of an overdose of the injection. If the injection be pursued too long the formic aldehyde will unduly irritate the lung tissue and increase the symptoms. It is only practice and experience which can tell one when to suspend the treatment, but, as a general rule, I should think it desirable to give up the injecticns for a few days when the temperature has fallen, when the sputum has become mucous and frothy, and when the cough is unduly troublesome. With regard to the latter symplom I do not see the same objection to treating it by opium as obtains in ordinary coughs. This cough is due to iritation of the pulmonary mucous membrane, and the same irritati $n$ causes the excessive secretion of mucus. An opiate will relieve both and is not, I think, counter-indicated.

Though it is somewhat outside our present subject, I may here mention the results of the treatment on bronctiectasis As you know, scarcely anything can have a fouler smell than the sputum from this complaint, and at times so bad is this symptom as to incapacitate the patient from intercourse with his fellows. A patient came under my care at Brompton who had been supposed to be suffering from this, though I found that he really had a tuberculous cavity of the base of the lung with pleural adbesions, which kept the walls of the cavity constantly stretched.
This was a similitude of bronchjectasis. His sputum was very offensive, so much so as to render it undesirable to keep him in the same ward with other patients. It separated on standing into the three usual layers. At this time I bad not given a greater injection than two cubic centimetres and that by the syringe. After even the first injection distinct improvement was observed in the condition of the sputum. It became almost devoid of odonr, less purnlent, and much less copious. He left the hospital much improved. I have treated a few typical cases of bronchiectasis similarly and with like, though not such immediate, results. But my last case requires special mention. My colleague, Dr. Percy Kidd, asked me to apply the method to one of his patients at the Brompton Hospital. The patient was a country policeman whose buonchiectasis and accompanying condition were so bad that he had been warned to leave the force if he could not get better. He was really unfit to associate with bis fellow men. He had been treated by inoculations in our "guaiacol room," but when I saw him he was in a wretched condition, although he had showed some slight improvement. At this time he was coughing up much more than a pint per day of very foul sputum. I began with the two cubic centi. metres of jnjection on each day and afterwards administered 50 cubic centimetres of injection by means of the burette. He rapidly improved and wben I last saw him he was expectorating only three ounces of matter which bad only a faint odour. He then had to leave the hospital in order to report himself so as not to lose his pension, but I bave little doubt that he could have been permanently cured.

[Since delivering the lectures I have tried, by modifying the vebicle, to use a greater strength of the formic aldehyde solution. At present I will not give details, but $I$ think the result can be accomplished. I purpose bringing the whole matter before one of our societies at an early date in order that it may be adequately discussed.]

\section{ABSTRACT OF THE}

\section{整urtors}

DIETETIC PROBLEMS.

Delivered before the West Kent Medico-Chirurgical Socitty on Dec. 7 th, 1960 ,

\section{$\mathrm{BY}$ GEORGE VIVIAN POORE, M.D.,} F.R.C.P. LoND.,

PROFESSOR OF THE PRINCIPLES AND PRACTICE OF MEDICINE, UNIVERSITY COLIEGE, LONDON.

DR. POORE commenced his address by expressing the pleasure which it had given him to accept the honourable duty which the society had asked him to perform, after which he referred to his anxiety first of all to do honour to the senior member of the University of London, and secondly, to do his best to keep up the reputation of the Purvis Oration. He said that he had taken for his subject one that must be in the minds of most of his hearers at the present moment, but he would like at the same time to explain that this particular subject was chosen some months ago and though it happened to be a singularly appropriate one in view of the crisis in connexion with beer that had arisen in some parts of the country, his selection was necessarily made without any reference to that state of things and without any knowledge that such an event was. likely to bappen. Charles Lamb in one of his well-known essays rather found fault with the members of a certain nation because they were too positive in their utterances. He said that they never seemed to be in doubt; if they were orthodox they were orthodox, and if they were infidel they were infidel, bnt they never seemed to wander in the dim twilight of dubiety. So far as the West Kent MedicoOhirurgical Society was concerned Dr. Poore deprecated this charge being brought against himself, because it was owing to the fact that the twilight of dubiety had settled 
upon him in regard to some dietetic problems that he had ventured to address them.

Nothing in this world, he continued, made entirely for good and nothing entirely for evil: roses had thorns and silvery fountains contained mud. We had to balance our acsounts and see on which side the benefit lay. Nothing was more remarkable than the change which had come over the dietary of the prople of England in the last two centuries. At his clab the other day he had taken down an old book of household accounts of the sovereigns of England extending from Elward III. to William and Mary, and it was curioas to read how limited was the diet of people living in what was then considered to be the lap of luxury. Princes lived practically on fish, flesh, fowl, and beor, and on very little else. It was true that in addition to beer there were other fermented beverages such as wine and drinks made from honey, but many of the articles of diet which we of the present day consider essential were then remarkable for their absence. Sugar and spices were mentioned as real luxuries. Fresh vegetables were hardly montioned at all, and but for the occasional intriduction of pipoins, referred to by Shakespeare, there wis a lask of almost all fresh fruit. It was hard to imagine at the present day a dietary table without tea, coffee, cocoa, fresh milk, and such like, and without fresh vegetables. It must be remembered how late it was in the history of this country before the potato was introduced into dietetics. It was not till 1767 or somewhere thereabouts that it was introduced into the dietary of St Bartholomew's Hospital. A country gentleman some years ago showed Dc. Poore some old half.yearly rent audit books and on the front page of the $b$ sols were the summer and winter bills of fare for the feasts which took place at those andits. As late as 1780 no mention was made of the potats. The diffifulties a couple of centuries ago in getting fresh meat, and especially fresh vegetables, in the winter montbs were very great indeed, and it was not until the improvement of agriculture and the introduction of the turnip and other roots as foodstuffs, and the subsequent improvement in horticulture and gardening, that fresh vegetables were at all available for the masses of the people. It could be quite well understood that scorbutic tendencies must have made themselves evident in the winter, and "spotted fevers," and the "purples," and the "bloody flax," and other diseases which had a scorbutic taint about them must have been rife But with the improvement of agriculture and the advent of free trade this state of things passed away. There could be no doubt whatever that the admission of corn to this country free of duty, and food of all kinds at rates against which the home producer was powerless to compete. had improved the dietary of the population at large. When he considered the variety of foodstuffs which were grown in foreign countries and reflected how London was the best mart in the world -one where most things could be got at moderate prices, where bananas were almost as cheap as turnips and pineapples were not the exclusive luxury of the rich-he felt that probab'y to this fact more than to anything else we owed the approximate abulition of typhus fever, the total abslition of scorbutic diseases, and the general improvement of the public health. Erasmus had said in the sixteenth century that the masses of the British people were fed as well as the monarsh, and this remark was not altogether inapplicable at the present day. There must, however, be something that had put a check on the improvement of public health which had undoubtedly taken place, and there were certain facts which must make us pause. One of these facts was the diminution of the birthrate. Jast at present the birth-rate had diminished more than the death-rate, and if we looked at the subject fairly we must see that there must be some lack of stamina in the people at large. Another cause for uneasiness was the large number of people living at the expense of others and those who found it impossible at the present day to maintain themselves in a condition of independence. He hesitated to speak of these persons as paupers because the word pauper had a political connexion, but the fact remained that there was an enormous number of people who lived in workhouses, asylums, prisons, and otber rate-supported institutions, and the number of such persons seemed to increase ratber than to diminish. There might be many explanations of this phenomenon, and he was unwilling to speak too positively of its causes. Infant mortality, again, did not show the diminution that was to be desired. The mortality under one year of age was as great as ever and we knew that these children had succumbed to dietetic diseases such as diarrhœa. Rickets was also a dietetic disease, and Barlow and Cheadle had pointed out that scurvy occurred among young children in consequence of dietetic errors. Then, again, women had largely given up the sacred privilege of suckling their offspring and they allowed their children to be brought up on advertised proprietary foods. It was impossible to avoid thinking that the enormous amount of dental carries must be due to some error or deficiency in diet. Most of those who worked in the City of London suffered from dyspepsia, and gastric ulcer was not less common now than it was formerly. Was it rot pussible that this was also due to some deficiency of iet?

In spite of all that had been done for public bealth the British constitution seemed very vulnerable to enteric fever whether in this country or in South Africa, and it was impossible not to mention in connexion with it the insidious increase of malignant disease which puzzled every one. Another subject worth considering was the hand feeding of infants, a difficult question for the solution of which chemistry had been invoked. Attempts had been made to imitate human milk by various manipulations of the milk of the lower animals, but the chemical question was not the only one, for biological and other conditions must influence the digestibility of such milk. He was inclined to think that milk in the mammæ was entirely different from milk in vitro. When milk was withdrawn from the mammæ it underwent certain physical changes. It was exposed to infection and accidental contamination, its temperature fell, and it began to separate into its constituent parts ; moreover, in a few hours it might become sour. Just in proportion to its remoteness from the mother in point of time the milk was more and more unsuited for the nourishment of the suckling. When a young animal was joined to the mother it was joined very much like the bud on the stock. It took in nourishment without exposure to the air or a fall in temperature, and the whole process was altogether unlike the taking of milk from a feeding bottle. Under natural conditions the child sucked a thin stream from the living cells of the mammæ direct into its own stomach, and surely that was a very different thing from taking half rancid food through a rancid indiarubber tube. On this matter we had little positive information, and although obstetricians were quite unanimous that breast feeding was in every way superior to band feeding still when facts and figures were asked for they were not forth. coming. He had only been able to avail himself of one instance, the data being supplied by a medical friend who had three cbildren, all thoroughly healthy babies. This gentleman had furnished him with figures which showed that two of the children, hand fed, had at the end of 11 weeks gaiced 37 per cent and 25 per cent. respectively on the birth weight, while the third child, which was nursed at the breast, showed at the end of the same period an increase of 84 per cent. This was very remarkable, esp scially when it was added to the consensus of opinion in the matter. Of course the use of milk for failing health was common; his hearers would remember that in medical history there were accounts of invalids who had recourse in their extreme old age to the services of a wel nurse, and it is reported that Dr. Caius, the President of the Royal Society, had to be fed in this way. He was rather a petulant old gentleman, but when he got a sweet-tempered nurse his temper completely changed. Many years ago he (Dr. Poore) was called in to see a patient who belonged to the upper classes and who was in a pitiable state, the result of bulbar paralysis. This gentleman was attended by Dr. W. B Cheadie, but about once a month he would become restive and on one occasion be called in Sir William Gull who told him that he wanted a little nourishing food and that at 11 A.M. each day he was to have half a pint of ass's milk with a petit verre of noyean. The ass was driven to the door each day and the patient had the milk hot from the animal. The prescription was entirely Sir William Gull's, but it was represented as his opinion conjointly with those of Dr. Cheadle and Dr. Poore. Whether in consequence of the treatment or not the man lived for three years. $\mathrm{O} a$ looking back at this case Dr. Poore was not at all sure that the prescription was rot the cause of the prolongation of the man's li'e. Much was heard of the dangers of milk, most of which were attributable to the manipulation of the milk itself. Of the disease attributable to the cow we had very little certain knowledge. It had been proved that tuberculosis might be conveyed to the lower animals fed upon milk from a tuberculous udder, but we were very much in the dark as to the part which milk played in the causation of tuberculosis in man. 
Evidence on this head ought to be forthcoming before drastic laws were passed regulating the supply of milk. In a herd of cows belonging to the best-known family in this country 38 out of 40 were found to be tuberculous, and this state of things had probably existed for many years. Alongside of this herd was a family of four generations, and as far as he knew there had not been a case of tuberculosis in that family. They should therefore pause before directing that all milk ought to be boiled. Variola and tubercle were diseases common to human beings and to cows. How was it that the variolous cow was at a premium and the tuberculous cow at a discount? He felt that children fed upon boiled milk were likely to suffer in health and that that deterioration in health might lay them open to tubercle. Milk that had been manipulated, whether sterilised or otherwise, ought to be labeled so that all might know what they were buying. Again, a habit was growing up of putting chemicals into the food of children. As a profession medical men ought to resist this. Enough was not as yet known about boric acid and it was disgraceful to make experiments upon babies. With regard to meat he thought that it was best when it was fresh, and most nourishing probably when it was raw. Of late years we had had a revelation in dietetics in relation to the thyroid gland. It was known that when thy roid extract was administered in suitable cases the stunted idiot would grow and develop physically and mentally and the myxoedematous woman would recover her health. That was a most remarkable thing. It was still more remarkable when it was remembered that this power of the thyroid gland was greatly decreased with staleness and was practically abolished by cooking and that the chemist could tell very little about the difference between the cooked and the uncooked gland-the one potent for action and the other that had no action at all. There was a belief, especially among the poor, that beef was most nourishing when raw, and this was probably not mere prejudice. The oyster-almost the only animal food that was taken raw in England-was known to be extremely digestible and stimulating. He reminded his hearers that one of the advantages which the South African Boer had had over us was in regard to his food. With a lump of biltong, the sun-dried flesh of the deer or ox, his commissariat was complete. British officers who had eaten biltong were all loud in its praises. He also referred to the charqui of Sonth America, the pemmican of North America, and the hung beef of Hamburg. When animals were put to stress for food-when, for instance, dogs or cats were about to have puppies or kittens-they were very active in finding fresh food. When he saw his cat hunting for mice or stalking birds in a more than usually active manner he was perfectly sure that there was a litter of kittens in the coal-cellar. His friend Dr. Taylor had been carrying on some experiments for him with regard to the digestibility of muscle. The fresh quivering muscle of a rabbit, muscle in the condition of rigor mortis, and muscle when the rigor mortis had passed away, were respectively put into similar mixtures of pepsine and hydro. chloric acid. In the fresh muscle the digestibility was 25 per cent. more than in the other samples. They seldom ate food that was absolutely fresh. To show that absolutely fresh food could be eaten with relish he instanced a case in the war in South Africa. A herd of deer were surrounded, killed, skinned, cooked, and eaten at once. It was an interesting thing to note that it was said that a coursed hare could be eaten on the same day that it was coursed, but on the other hand a hunted stag was an impossible food. He mentioned this because it was one of those things of which he should like to have more knowledge. Finally he asked what it was that happened to meat when it was hung and ripened? He could not give the answer, but he strongly suspected that there was a microbial action concerned. It was the cultivating medium which stimulated our appetite.

They were apt to look too much to chemistry in the matter of food. Who when they ate considered whether they were taking too much carbohydrate or tos much proteid? It was what they digested that did good, and this depended on whether it was stvoury and stimulating to the glands of the palate and so forth. If a person sat down to a repast selected so as to contain a certain percentage of proteids it was very likely that the stomach would rebel. He thought that there was too much of this sort of thing and that physiological chemistry was doing itself no good by it. $\mathrm{He}$ could not help thinking sometimes that there were manufacturing firms who kept chemists very much as advertising tailors used to keep poets and for the same reason. In conclusion, Dr. Poore referred to "shop eggs" and to the difference between fresh and frozen meat. He also gave a humorous account of a visit to a village on a Saturday night where the grocers' shop-windows were filled with potted vegetables and where the smell from shops in which slabs of semi-transparent flabbiness were frying in oil could be appreciated a quarter of a mile away. Replying to a note that was handed to him asking for his opinion on the doctrine of not taking any meat, he said, "All flesh is as grass."

\section{THE CONDI'TION THREE YEARS AFTER OPERATION OF FIFTY SUCCESSFUL CONSECUTIVE OVARIOTOMIES;}

FIVE PATIENTS LOST SIGHT OF, 32 IN EXCELLENT HEALTH, SEVEN OASES NOT QUITE SATISFACTORY, THREE UNSATISFACTORY, AND THREE PATIENTS DEAD. ${ }^{1}$

(Notes of some cases refused operation and of the anthor's un published fatal cases of ovarnotomy are added.)

BY JOHN D. MALCOLM, M.B., C.M., F.R.C.S. EDIN SURGEON TO THE SAMARITAN FREE HOSPITAL.

THE statistics of ovariotomy have been made a subject of competition amongst surgeons, and it may be admitted that when the operation was new and its mortality was great the rivalry served a useful purpose, but now that the mortality is small the announcement that one has attained the lowest death-rate is apt to prove misleading; for the fact that a surgeon is able to publish a series of 50 consecutive recoveries from ovariotomy has not necessarily any scientific or clinical value. Even a much larger number of consecutive successes might be recorded without proving any special skill in the surgeon, whilst, on the other hand, there might be no discredit to an operator in the occurrence of fatal cases under his care at short intervals. The man who has the lowest death-rate is not by any means necessarily the best surgeon. The mortality is influenced to a considerable extent by two factors which are quite independent of surgical skill. One of these is chance. A surgeon may have a long series of simple cases or of difficult cases, and this factor cannot be eliminated altogether in any number of operations. It is obvious, however, that a man who has the opportunity of performing ovariotomy very frequently is likely to be asked to undertake an undue proportion of operations that are difficult and dangerous, so that his death-rate might possibly be increased in consequence of bis recognised ability. It is also obvious that if a surgecn selects a series of cases from his work, as I have selected the cases which form the subject of this paper, the results recorded may offer no indication of his true death-rate. A brilliant series of successful cases may by chance be part of a very poor record.

Another factor which influences the death-rate is the care and skill with wbich the cases for operation are selected. Some of the authors of statistical papers on ovariotomy have asserted that they made no selection of the cases operated on. I do not understand such an assertion. Every surgeon. must select his cases. It is hardly possible that a surgeon could see a large number of patients with ovarian tumours wilhout meeting with a malignant ovarian growth which he could not remove. If he has met with such a malignant case and has not operated on it, whilst asserting that he has made no selection of cases for operating, he really makes an unjustifiable claim.

I have elsewhere pointed out ${ }^{2}$ that a statistical paper on. ovariotomy has little or no value unless it is accompanied by an account of the cases simulating those of ovarian tumour in which the surgeon has declined to operate, but I do not know of any series of cases in which this plan of publication has been adopted. In the series which $\mathbf{I}$ am now about to consider there are three cases in which the mistake of

1899.

2 Illustrations of Some Modes of Death after Ovariotomy, Transactions of the Royal Medical and Chirurgical Society, vol. lxxviii. 